\title{
A DOUBLE-EDGED READING OF GOURLAY'S CHILDREN FICTION BOOKS
} (Dis)Empowering the "Invisible" Filipino Community in the UK

\author{
Neslie Carol C. Tan \\ Department of Literature, De La Salle University \\ neslie.tan@dlsu.edu.ph
}

\begin{abstract}
This paper conducts a double-edged reading of Candy Gourlay's two children's novels, Tall Story (2010) and Shine (2013). It argues that on the one hand, these two award-winning books empower the "invisible" community of Filipinos in the UK by foregrounding the "subalterns" and narrating (with subtle social commentaries) their migrant motivations and woes. These narratives are further enriched by folkloric and supernatural twists that orient global audiences as well as younger generations of Filipinos abroad on Filipino cultural heritage. On the other hand, the representations embedded in these narratives contain traces of self-orientalism, reinforcing essentializing binary divisions where Filipinos or "Orientals" are stuck with the negative attributes and the "happy endings" also push the minority group further into the margins vis-à-vis the privileged British center. Hence, the kind of visibility accorded to the Filipinos by these market-approved children's novels may be deemed problematic and the role of Gourlay as an immigrant writer bearing the burden of representation is then explored.
\end{abstract}

\section{Keywords}

Children's/Young Adult Fiction, Filipinos in the UK, (Self-)Orientalism, Representation, Candy Gourlay

\begin{abstract}
About the Author
Neslie Carol Tan is a part-time lecturer at the Department of Literature of De La Salle University, Manila. She holds a Master of Arts degree in Cultural Studies at the School of Oriental and African Studies (SOAS), University of London. And she is currently on leave to pursue $\mathrm{PhD}$ at the University of Melbourne under the Melbourne Research Scholarship and the Faculty of Arts - Dean's PhD International Scholarship awards.
\end{abstract}




\section{INTRODUCTION}

\section{Filipinos Everywhere...or Nowhere?}

The Philippines is considered a major source of human capital for countries around the world (Santos "Why Filipinos Left"). The mass migration of Filipino workers to the UK in particular resulted from the "political and socio-economic turbulence in the Philippines [which] coincided with large scale British recruitment of foreign workers" in the mid-196os (Legarda-Alcantara et al. 34). Due to the race riots in 1962 and the rising public fear of immigrants, the UK government legislated the Commonwealth Immigration Bill in 1972, effectively restricting the entry of commonwealth immigrants. Hence, the National Health Service (NHS), hotel, catering, and other domestic industries had to turn to other countries for cheap labor. Filipinos, struggling under the Marcos regime, took advantage of this shift. Around twenty thousand work permits were offered to Filipinos in this first major human traffic from the Philippines to the UK from 1968 to 1980 (35). In the new millennium, the demand focuses on Filipino professional nurses in particular as they fill the professional skills gap in the UK medical industry. The recruitment has been so aggressive that in the early 2000 , close to forty thousand work permits were issued to Filipino nurses (28). The last UK census (2011) reported having around two hundred thousand Filipinos in the UK, with most living mainly in Brent and Hounslow in Outer London, and Newham and the Kensington and Chelsea boroughs in Inner London ("The South-East Asia Diaspora in the UK," 3).

After decades of settling in the UK,Legarda-Alcantara et al. (135) asserts that Filipinos are "now a viable, active community" as evidenced by the growing number of laborers in the country and by the increasing number of businesses catering to the community such as remittance agencies, The Filipino Channel, Filipino-owned restaurants and supermarkets, etc. The social and cultural life of the community is active and varied, often along regional affiliations (134). A Filipino festivity called Barrio Fiesta sa London is even celebrated every July at Lampton Park, Hounslow (138).

But despite these marks of being "settled" in the UK, Popiel (191) aptly observes: "You cannot see the Filipino culture in the UK unless you look for it." The Filipinos remain an "invisible community," living quiet lives due to the stigma of working as domestic helpers or caregivers despite high educational attainment (LegardaAlcantara et al. 78). What little visibility they do have is their reputation of being reliable, honest, and hardworking-fitting qualities for caregivers or domestic helpers that at some point 'Filipina' became equated with 'maid'(78). 
General confusion over technical social categorization in the UKmay havealso inadvertently contributed to the "invisibility" of the community. In her blog post "Relearning the coulour of me" on October 5, 2012, Gourlay explains that back in the 1980s, the official forms in the UK only had three classifications: White, Black, or Asian. Contrary to our usual categorization, "Asian" among the English is limited to only the people from the Indian subcontinent. Also, very few Filipinos availed of Black and Minority (BME) services available to them: "They saw the 'Black' bit and never applied for the services." Moreover, Corbyn ("Ticking All the Right Boxes") reports that this confusion has also affected the Filipinos' proper recording of information in the UK national census. With "old-fashioned" ethnic categories like "Asian or Asian British" being different from "Chinese and Other," two-thirds of UK Filipinos ended up identifying themselves as "Asian Other," while the rest chose "Any Other Ethnicity" in the 2001 UK Census. There was thus no proper consolidated accounting for the growing Filipino community in the UK.

Hence, during the last UK national census in 2011, the Philippine Embassy in London and the organizations One Filipino and Philippine Generations made it a point to campaign for Filipinos to "tick the right boxes" and declare their ethnicity as "British Filipino" or "Filipino" under the "Other Asian background" (not under "Any Other Ethnicity") category. The census happens only once adecade and is a critical source of information that shapes economic and social policies at the national and local government levels, so this last census was an important platform to let the UK government know about the "true strength, spread and presence of the Filipino community" (Corbyn, "Ticking All the Right Boxes").

\section{The Promise of Visibility through Literature}

Fortunately, apart from efforts like this campaign for proper categorization, literature also has a way of writing/narrating the "invisible" into visibility. As Said (Culture and Imperialism xiii) asserts, "stories are at the heart of the world." They have the power to assert identities and histories. Even in the imperialist battleground, the key issues were "reflected, contested, and even for a time decided in narrative ... [so] the power to narrate, or to block other narratives from forming and emerging, is very important to culture. . "' (xiii). In the context of Filipino American literature, de Manuel recognizes the power of contemporary Filipino American novels in affirming the existence of the forgotten Asian Americans. She claims that these literary works Filipinize the American experience "through the insertion of the story of the colonial subjects into American history" (102). 
Now, in the context of the UK, perhaps this same power of literature can be gleaned from Candy Gourlay's children's books. Gourlay, a Filipina journalist-turnedchildren's fiction writer based in London, has been gaining fame in the Children's/ Young Adult Fiction field with the publication of her two award-winning books Tall Story and Shine. Both novels have been shortlisted for many literary awards and both have also won the prestigious Crystal Kite Prize for Europe (the only peer-given award in publishing for young readers) in 2011 and 2014, respectively. The former also won the National Children's Book Award in the Philippines in 2012. These children's novels do not only provide literary entertainment, but also raise awareness about an "invisible" immigrant community in the United Kingdom: the Filipinos (MacAlpine 13). Also, as two of the very few English publications by a Filipino about the Filipinos in the UK, these books also function as vehicles for the transmission of culture to second-/third-generation Filipinos in the UK, informing them of their grand/parents' home/land and culture. Considering their wide reach (published in the UK and the US by David Fickling Books, and in the Philippines by Cacho Publishing and Anvil Publishing) as well as their potential influences, the books' representations of the Philippines, the Filipinos, and their culture are interesting subjects for cultural study.

Growing up with books featuring "blonde children who lived in houses with white picket fences" instead of "noisy, bustling home in hot, sweaty Manila on the edge of a slum in the Philippines," Gourlay ("Multicultural is not about difference") realizes the dearth in multicultural books. This is an issue others have also raised especially in the supposedly multicultural UK where ethnic groups are still absent or are underrepresented both as characters and writers or illustrators (Lazim, "Reading Our World"; Kean 8). Gourlay thus recognizes the need for Filipinosto tell their stories in order to "exist" in the UK. She shares in an interview with Mariano of the Sambat Trust, "We must tell the world our stories, in our own voices." With this sentiment, Gourlay assumes the role of the immigrant writer whose children's books could make visible the "invisible" community of her people and present "stories formerly suppressed or elided" (Bradford 217) to new generations of readers.

It was not an easy process for a Filipino writer to penetrate the UK publishing industry. In the team blog "Notes from the Slushpile," maintained by Gourlay along with seven other children's authors at different stages of the publishing journey, Gourlay documents the difficult process she has undergone to become a "proper author."Accordingly, it was in 2004 that she started to become serious about getting published, and so she attended talks, conferences, and networking opportunities, as well as blogged about these experiences to help her process the whole business of children's publishing. She also joined the Society of Children's Book Writers and Illustrators (SCBWI ${ }^{1}$ and the Society of Authors. ${ }^{2}$ After six years of blogging and 
another nine years of trying to get published, she finally cinched a book deal with David Fickling Books (then still with Random House).

In her video blog post addressed to the students of Theresian School of Cavite, Philippines, on July 29, 2012, Gourlay speaks (in her rarely heard "Filipino English" accent) about her primary audience:Filipino children. She confesses to thinking about this particular audience as she was writing Tall Story, wondering if they will read it, enjoy it, and perhaps even be proud of themselves afterwards. She considers her books as her love letters to the Filipino children readers.

However,the reach of her books has extended beyond this target audience.In fact, both books are classified at different grade levels in the UK/US and in the Philippines. In the Philippines, her books are classified as Young Adult books fit for twelve to eighteen year-old readers. But in the UK and the US, Tall Story caters to a younger crowd: middle school students (which corresponds to the age group of nine to thirteen year-olds) or even younger. Shine, on the other hand, is most comfortably read by "all ability readers starting at Year Eight (12 years old)," although Gourlay shares that she has received fan mails from Year Sevens (eleven years old) as well.

Furthermore, Gourlay's role as a writer does not end with the publication of her books. She actively posts study guides using SlideShare, thus sharing reading tips and creative projects students may undertake to respond to the characters and the issues they face in her novels. She also has frequent paid school visits ${ }^{3}$ in different schools in the $\mathrm{UK}^{4}$ (and even in the Philippines and Hong Kong during her trips back home), ${ }^{5}$ which were all received enthusiastically by her young readers.

All of these general activities and acclaims support what Ramon Sunico, the publisher responsible for the Philippine edition of Gourlay's books, asserted, "[She] is already way past the realm of Philippine literature-that's the significant thing above all. She is part of the British YA lit scene now, and that she persists to write for us as well is a great act of patriotism" (qtd. in De Vera, "Identity crisis spawns two books").

Given the significance of Gourlay's two novels, this paper will thus illustrate how both Tall Story ${ }^{6}$ and Shine $e^{7}$ pose double-edged potentials and risks: On the one hand, these books can empower a minority by putting into print their (migrant) existence, thus creatively affirming their presence in the multicultural UK landscape. But upon closer examination, I argue that the kinds of representation embedded in these novels may also raise problems on the quality of the visibility given to the "invisible" group. The books may counter-intuitively reinforce Orientalist stereotypes and drive the minority group further into the margins vis-à-vis the British center. After

Kritika Kultura 28 (2017): -304 
problematizing both sides of these double-edged representational consequences, I will then explore their implications on the role of an immigrant writer.

\section{EMPOWERING THE "INVISIBLE" COMMUNITY OF FILIPINOS IN THE UK}

\section{Subalterns Speaking: Focusing on the Filipino Immigrant Condition}

Gourlay's children's novels empower the "invisible" Filipino community in the UK by foregrounding them. In doing so, she includes the Filipinos in the cast of characters whom young readers are used to; in this way, she also subtly addresses critical Filipino immigrant issues. Gourlay uses the children's voices to raise awareness about the general themes characterizing Filipino immigrant conditions in the UK, such as theirspecific migration motivations, visa application struggles, consequences of children left behind, as well as homesickness and nostalgia.

Gourlay has deliberately given voice to the "voiceless" (some literally) characters in both of her dually-narrated books. For Tall Story, Nardo speaks "broken" English and his half-sister Andi does not have any say in family decisions because of her age; meanwhile, Shine is narrated by mute Rosa who, due to "the Calm," can only express herself through sign language or through technology, and the ghost of her mother, Kara, who can narrate only the past.

All four narrators experience "subalternity," occupying a subordinate position vis-à-vis an economic, social, racial, cultural, and generational (age) dominant center. They are "subalterns" not only because they occupy social groups outside the British hegemonic power structure (since they are half-Filipinos living in the UK or outside of the UK in some chapters), but also because of their physical flaws or peculiarities that mark them as outsiders even within their hometowns in the Philippines. Moreover, apart from Kara, the rest of the narrators are young (thirteen to sixteen years old) and are thus automatically "othered" from an adult perspective (Nodelman 32). As kids or teens, they have little or no power in family negotiations or decision-making processes and are generally "vulnerable to social and cultural forces" (McGillis 217).

But Gourlay allows these silenced subalterns to speak about Filipino immigrants in the UK, specifically the conditions and consequences of their migration. A recurring push factor in both novels is the dire economic conditions in the Philippines. In Tall Story, Andi recounts how her mum, Mary Ann, was compelled to work in London during "the worst time in her life": she was ill, bereaved, had just given birth to Nardo, and was deep in debts. And since "nurses in the Philippines

Kritika Kultura 28 (2017): -304

(C) Ateneo de Manila University

$<$ http://journals.ateneo.edu/ojs/kk/> 
don't earn gazillions" (Tall Story 23), nursing abroad became a recurring solution or pull factor to the UK. Even in Shine, Kara recalls how Kat considered the newspaper article report on "world nursing shortage" as their ticket out of Mirasol (16).

The migratory impulse gives context to the plots and sets into motion the migrations of the next generation of characters: Nardo (Tall Story) and Rosa (Shine). They also allow Gourlay to subtly critique the forces that make what she calls an "act of total desperation to leave everything you love behind" a norm among the Filipinos (Schmidt 42).

These recurring pushand pull factors reflect a real contemporary migratory pattern of Filipinos going to the UK. For instance, Buchan (119) explains that the Philippines has become a key source of international nurses for the UK since it is one of the few selected sources of "ethically acceptable" nurses stipulated in the NHS Code of Practice of International Recruitment (114). Coincidentally, just when the UK was experiencing nursing shortage in the first part of the $21^{\text {st }}$ century, there was also a reduced demand for Filipino nurses in their more traditional work destinations (e.g. the United States and the Middle East). Hence, Filipino nurses turned to the UK and a total number of 24,00o Filipino nurses were registered in the UK between 2001 and 2010 (116).

Overall, the trend of Filipino nurses migrating to the UK has contributed to the Philippines being "the leading female migrant sending country" in Asia, with over 72 percent of its total migrants being women working as nurses, caregivers, domestic helpers, or entertainers abroad (Reyes 1 ). While the economic benefits of migrant laborers cannot be denied, the social costs of this set-up, especially on the children left behind, is a serious concern that cannot be ignored. This issue becomes more critical in light of Scalabrini Migration Center's claim that families experience more disruptions and undergo more adjustments when women migrate instead of men (56-7).

Gourlay has long investigated this consequence of migrant labor. In 2005, she wrote and presented a BBC Radio 4 documentary entitled Motherless Nation addressing the issue of children left behind by migrant Filipino laborers (Baines, "Interview with a Debut Author"). A decade earlier, she also handled a project for the pan-European magazine Filipinos in Europe, for which she visited Filipino communities in Europe and interviewed women who chose to leave their families behind to work abroad. In the end, Gourlay inquires into the worth of their sacrifice, given the heartaches caused by it (Schmidt, "An Interview with Debut Children's Author"). 
Thus, Gourlay confronts this same issue in her children's fiction, especially in the case of Nardo (although such is also apparent in Kara's and Rosa' cases). In Nardo's case, he is the child left behind, and he has been waiting for his immigration papers most of his life. Even Andi, on the other side of the globe, has also witnessed their Mum's “years of paperwork and overseas phone calls" just to bring Nardo to London (Tall Story 23). This situation also opens up space to critique the immigration system in the UK, which sometimes denies the visa petitions of Filipinos (Baines, "Interview with a Debut Author").

Still, Gourlay acknowledges that the immigration system has improved through the years: nurses are now permitted to bring their immediate families to live with them, and many long-term workers have been granted proper status, allowing them to continue their careers and pay taxes in the UK (Schmidt, "An Interview with Debut Children's Author). In another interview by Baines in 2014, Gourlay accedes that Nardo's problem would be considered an "aberration." However, anxieties over immigration have started anew with the recent Brexit, in which the Britons voted to leave the European Union in the referendum last June 23, 2016. As of now, there is still much uncertainty regardingthe exact immigration policy changes that will take effect after this vote. However,Wheeler and Hunt report that Prime Minister Theresa May considers the British people's desire for a considerable reduction in immigration as one of the key messages of the Leave vote.

Aside from these social commentaries on torn Filipino families and the (overly) strict visa processes they are subjected to in order to enter the UK, these subaltern narrators also bring to fore the "invisible" community's struggles adjusting to a new culture and their perennial state of homesickness.

Reyes explains that some of the new challenges migrant children encounter are culture gap and identity confusion (17). This is apparent in Tall Story, where upon his arrival in London, Nardo behaved like he "stumbled upon an alien landscape" (85). Everythingseems to be a struggle for him. But the most obvious adjustment is speaking in English. Andi realizes this immediately when she hears Nardo's hard vowels ("Ay kennat bileeb" for "I cannot believe") (85) and his wrong grammar ("Michael Jordan is my biggest fan" to mean that he is the biggest fan of Michael Jordan) (96). Painfully aware of his own lack of English proficiency, Nardo would repeatedly apologize, "I have sorry. My English is . . barok" (broken) (169).

Then there are the pangs of homesickness that migrants, whose wishes have been fulfilled, still grapple with. For example, Nardo would wince as "something thrust hard, deep into [his] heart" whenever he thinks of his friends back home (Tall Story 133). He would compute the time in the Philippines and his mouth would water upon remembering his usual Sunday feast (134). Even Kat, who was

Kritika Kultura 28 (2017): -304 
eager to be away from Mirasol and from her twin, "cracked" after a year in London, requesting Kara to join her (Shine 137).

These sentiments echo the nostalgia that also pervades Filipino American literature, the "traditional or experimental, iconoclastic or classical, young and old writers alike share a nostalgic mood when their characters recall the Philippines where they spent their childhood and/or youth" (González 42). Nostalgia and homesickness permeate the lives of characters who would keep all sorts of Filipino mementos in their home, listen to waves that remind them of home, and cry while listening to Filipino songs played at a barbershop (42).

Just as Filipino American writing "nurtured on American shores" delved in "motifs of departure, nostalgia, incompletion, rootlessness, leave-taking, and dispossession," so have Gourlay's two children fiction books dabbled with the same issues (Solberg 1983 qtd. in Abad-Jugo 6o). It is hence by bringing attention to and affirming these immigrant conditions and sentiments that Gourlay's books empower the "invisible" community of Filipinos in the UK.

\section{Reviving Folkloric and Supernatural Roots}

Apart from the obvious foregrounding of the Filipino subject and their migrant experiences using the voices of the subalterns, Gourlay's novels empower the Filipino community in the UK by retelling important folklore and supernatural myths. This strategy not only orients diverse readers on the narratives that have enriched Filipino literary and cultural heritage, but also facilitates the transmission of culture to second- and or third-generation(s) of Filipinos abroad.

In particular, Tall Story draws heavily on the famous Filipino legend of Bernardo Carpio, a giant with immense strength who stopped two boulders from colliding and decimating a whole town (Miller et al. 21). Since Nardo's sudden impressive growth coincided mysteriously with the ceasing of regular earthquakes in San Andres, he is believed to be the reincarnation of this giant hero. This belief is strengthened when the first tremors of earthquake (the first one in three years) coincidentally restartedon the day their "savior" received a letter from the British Home Office finally approving his petition to migrate to London. Curiously too, Nardo started having mysterious seizures that are described precisely like the legendary giant's trapped condition: the earth bearing down heavily on his shoulders, mountains poking his nape, and rivers of water trickling down his arm (33). 
Since the roots of local Philippine children's literature can be traced back to pre-colonial oral folktales (Alba 15), it seems fitting that Gourlay builds upon them in her contemporary children's fiction. Gourlay claims, "We cannot escape our mythology because it lives and breathes in the natural environment of the Philippines" (Schmidt, "An Interview with Debut Children's Author"). Moreover, in recognizing that myths and legends are endangered genres because of their orality, Gourlay incorporates them into her novels with the belief that children's publishing will help archive Filipino folkloric heritage (Schmidt).

Moreover, she updates the old legend to contemporary realities, narrating a Bernardo Carpio in "a world in which globalization impinges on our most fundamental relationships, where a boy can be separated for most of his childhood from his mother, and where cultures inevitably come into collision" (Baines, "An Interview with Debut Author"). Ber/Nardo's spot between boulders/cultures becomes a kind of "liminal third space" where the minority/marginal can speak (Bhabhazoo).

Apart from this legend, other supernatural elements also drive the plots of both novels. On one hand, Tall Storyincludes a village witch and a wishing stone, while Shine features Yaya's spine-tingling ghost stories akin to those Filipinos have grown to fear back home (Paman, "Beneath the Pale Moonlight"). These supernatural elements, in a sense, also serve to introducereaders to Filipino Catholicism, which is "an amalgamation of ancient animist practices and modern beliefs" (Schmidt, “An Interview with Debut Children's Author).

Out of the many characters in Philippine supernatural lore, Gourlay focuses on the most common supernatural entity in native folklore: multo (from Spanish muerte), meaning "ghost." These entities are believed to have unfinished business, and are drawn to life forces such as the flickering of candle flames. Hence, Rosa lights a candle every night to summon her mother's ghost. To heighten the horror, "monsters" are also incorporated in different forms: disfigured patients of "the Calm" (Rosa, Kara, and Ansel 95/Danny), Yaya with her cleft palate, and Kat with her violent delusions.

This tendency among Filipino writers abroad to draw on Philippine folklore and supernatural beliefs is quite common according to Lapeña-Barayuga. In her unpublished dissertation, she explains that this is meant to maintain linkages with the homeland and stamp a distinctly Filipino voice and texture to their works. Filipino American writer Gonzalez has also noticed this pattern in Filipino American literature, claiming that the inclusion of the folkloric results in a kind of "Filipinization of America rather than the Americanization of Filipino migrants" (Gonzalez and Campomanes63).

Kritika Kultura 28 (2017): -304

(C) Ateneo de Manila University

$<$ http://journals.ateneo.edu/ojs/kk/> 
Overall, these folkloric and supernatural twists to the children's stories have added a distinctly Filipino angle to usual tales of migration. Additionally, this effort has been lauded in a number of reviews: De Vera observes that the "helpful facts and fascinating bits of Filipino folklore" add to the appeal of Tall Story, which covers real consequences of families coping with parents working abroad and struggling to fit in a new society ("Tall Story: Tale of 2 siblings, 2 cultures"). Meanwhile, Faber ("Shine and Picture Me Gone") welcomes the "steamy, tropical, contemporary version" of horror story in Shine, in contrast to the "cold and bleak English landscapes and Victorian" horror stories British readers are used to.

More than introducing the Filipinos to a global audience through folklore and supernatural mythologies, Gourlay's children's novels also play an important role in facilitating the critical transmission of Filipino cultural heritage to second- and/ or third- generation Filipinos in the UK. This effort is especially useful given Legarda-Alcantara et al's concern over the new generation of Filipinos in the UK who identify only with theirEnglish side, thus disregarding their Filipino roots (184). In a way, Gourlay admits that she is also writing for her own children ${ }^{8}$ who are all growing up and whose identities are "very English" but whom she wants to still be able to "see themselves" in her books and nurture "strong pride and love for the Philippines." (De Vera, "Identity crisis spawns two books").

This identity problem is exemplified by Andi in Tall Story. She finds her name "Amandolina" embarrassing, like an elf in The Lord of the Rings. Also, in her opinion, Tagalog is a language that sounds foreign: "Yakatakabaka yak taka babalaba" (94). She reflects the contemporary reality of younger Filipinos in the UK who straddle two cultures and grapple with issues of cultural identity and continuity of heritage (Legarda-Alcantara et al. 184). The earlier "straightforward" reasons for migrating (e.g. exile, employment, marriage, etc.) have grown more complex with the expanding Filipino community (i.e. new arrivals, as well as second and/ or thirdgenerations) and requires more "subtle analyses ... to reconcile differing world views." Subsequently, the migrant community is confronted by multiple questions of how (and by whom) the young generation is to be brought up and which identities they should adopt.

Indeed, children's literature plays an important role in cultural (re)production through time. They not only transmit literary legacies or classic narratives that "everyone should know about because they belong to the cultural heritage of a group" (Parlevliet553), but they also function as vehicles for the transmission of traditions and cultural capital that will enable succeeding generations to preserve and develop their cultural identities. In the case of Gourlay, with her creative incorporation of traditional folklore and supernatural stories in her two children's 
books, she preserves and passes on Filipino cultural heritage to dispersed young generations of Filipinos.

Thus far, I have identified the laudable efforts of Gourlay's two children's novels in making the "invisible" community of Filipinos in UK visible. Both Tall Story and Shine allow the silenced subalterns to speak of their stories prior to and upon arriving at the UK, thus opening up space for social commentaries on critical migrant issues that Filipinos abroad struggle with.These novels also pass onFilipino literary history and cultural heritage in the form of Philippine folklore and supernatural mythologies. This creative inscription of the Filipinos in the landscape of children's literature in the UK not only widens the cast of characters whom young readers are usually exposed to, but it also facilitates the transmission of Filipino culture and heritage to young second- and/or third-generation Filipinos in the UK.

\section{THE “OTHER" SIDE OF THE DOUBLE-EDGED READING}

But embedded within these "empowering" texts are risks of problematic representations. Hence, in this section, I will examine Gourlay's representational practices more closely in order to unpack the risks and repercussions involved therein. By exploring the nuances of her depictions of the Philippines, Filipinos, and their culture, I will expose the "othering" side of the double-edged discourse in the two children's novels and extend the exploration to Gourlay's role as an immigrant writer.

\section{Mind the Gap: Reinforcing Orientalist East-West Divide}

There are problematic geographic, cultural, and gender representations in Tall Story and Shine that have traces of self-orientalism, a tendency that has been prevalent in Philippine scholarshipaccording to Patajo-Legasto ("Introduction" xviii). These representations may, as de Manuel and Davis have warned, backfire in their efforts to educate audiences about diverse cultures and instead reinforce the "exoticism" of the Other (ix).

In terms of geographic descriptions, there is a clear dichotomy in the representation of the two locations central to the narrators' life stories. For instance, in the case of the Philippines, Gourlay focuses on small, far-flung towns in San Andres (Tall Story) and Mirasol (Shine), while the UK centers on the modern metropolis of London. 
Despite the modernity of twenty-first century Philippines, both San Andres and Mirasol remain fixed in their pristine, yet "backward" provincial conditions. San Andres is described for what it lacks: "no square, no supermarket, no bar, no church ... no clay-tiled roofs, no tidy pavements . . ." (Tall Story 6). But what it does have, in plenty, are earthquakes, dengue-causing mosquitoes, and corruption. Meanwhile, Mirasol, an island where rain never seems to stop, is preserved as an unspoiled mystical island with a "knowing" and "tragic" Mount Banawa at one end (Shine 27). These locales, like Said's concept of the "Orient," are stuck in a "bad sort of eternality" or a condition of unproductive immobility where any possibility of progress, human development, or societal transformation is denied (Orientalism 208). Moreover, Aziz has already raised this same issue in children's picture books, claiming that they "reveal an array of accepted worldviews about these countries ... [that] do not accurately depict the regions' sociocultural development” (44).

In stark contrast, London is positively imagined in the two children's novels. It is the right blend of tradition and modernity: "London with its spires, its knowing oldness, its absolute certainty ... gilded streets, museums and castles, hi-tech hospital, trains . . "(Shine 136). It exudes a sense of multicultural tolerance that dispels fear/danger: "It was such a mixing bowl, churning with people of every colour, every story ever told, every word ever spoken...No fingers pointing, nothing to hide" (136). Even what it "lacked" are shown as positive absences: there are no sounds of arguing neighbors, barking dogs, or crowing roosters. To add, nobody is bare footed (Tall Story 133). Andi summed it up best when she reminds her Mum, "Well, London isn't the Philippines" (3).

More than the geographic contrasts, the cultural gap between the Filipinos and the English is quite distinct. True to orientalist discourses (Said, Orientalism 205), the former is attributed with superstitious primitive faith, while the latter is associated with rational progressive science.

As discussed in many reviews, Gourlay herself recognizes the clear "tension between faith and science" in her works (Mariano, "Interview with Candy"). There may be some sense of cultural pride in reviving folkloric and supernatural beliefs, but the twists in the narratives depict faith in these superstitions as hindrances to progress (e.g. simple medical care). For instance, when Nardo reached the alarming height of eight feet, Aunt Sofia still stubbornly resisted confiding to Mary Ann:

Jesus Mary Joseph! Nardo, your Ma is a nurse. A nurse! She is a scientist, not a believer. She will spit on the soul of Bernardo Carpio and then what? Where will San Andres be? (Tall Story 45)

Kritika Kultura 28 (2017): -304 
It was only when he reached London, under the care of his "scientist" Ma, that Nardo experienced proper medical care. Suddenly, the superstitions could no longer hold up to the concrete scientific proofs generated from a series of blood tests, brain scans via MRI, and consultations with specialists. Nardo was diagnosed with gigantism, a condition where a tumor in his pituitary gland secretes excessive amounts of growth hormone. His seizures, which were initially thought to parallel the mythical giant Carpio's struggle while trapped between two mountains, are actually symptoms of his worsening condition, and thus arenot connected with the sudden recurrence of tremors in San Andres. Mary Ann could only lament, "If Sofia and Victor had told me sooner, we would have been able to do something and control his condition" (Tall Story 130).

The same pattern or juxtaposition applies in other cases: The "monster" within Kat, who goes through bouts of violent paranoia is diagnosed as "delusional disorder." Other "monsters" like Kara and Rosa, instead of being harbingers of death and danger, are given proper medications and precautions to help them cope with "the Calm," and Yaya's cleft palate is surgically fixed by Doctor Jon. Once these superstitions have been dispelled, science or logic also casts doubts to the existence and power of witches, wishing stones, and ghosts.

What is more interesting is how the opposition between the emotional/ irrational/superstitious beliefs and the logical/scientific/progressive thinking is also divided along gender lines. Consistent with orientalist gender division where the Orientals are linked to women (Said, Orientalism 207), the female characters are often attributed with irrational or uncontrollable emotions: Yaya turns herself into "cowering, scaredy old thing" with her own ghost stories (Shine 50); Aunt Sofia overflows with motherly nurturing intentions towards Nardo; lastly, even nurse Mary Ann is often depicted as bursting with uncontainable emotions (i.e. shrieking at good news and collapsing at the bad ones). Insanity or madness is also curiously assigned to women characters. For example, the town witch Mad Nena, driven mad with grief over her daughter's death, wanders around town in rags (Tall Story 26). Meanwhile, Kat, who suffersfrom delusional disorder, lashes out at her twin because of the "horrid, swarming thing" inside her (Shine 328).

In contrast, it is up to the British men of science, the dads in both novels, to offer some order to the chaos and present some logic to the "irrational" beliefs and emotions of the women and the confused children. Doctor Jon scientifically explained Kat's "monsters," and also trained Rosa and Yaya on the proper medical precautions for "the Calm." He is hailed in the Medical Journal for his brilliant work in helping patients of Mirasol "overcome stigma and superstition to live full lives" (Shine 243). 
Overall, these geographic, cultural, and gender representations reinforce orientalist East-West divisions where the East/Filipinos/Orientals receive the negative attributes in the arbitrary binary system. Ileto, a critic of orientalism in Philippine scholarship, has already warned against adhering to essentializing binary oppositions between positive Western values and negative Filipino values since they re-inscribe myths of underdeveloped ex-colonies and reproduce (neo) colonial discourses that inevitably represent Filipino for what they lack or fail to be or do $(5,30)$.

In her defense, Gourlay explains how these representations are intended to help empower Filipinos abroad who "lack self-esteem about our place in the world" and encourage them to be themselves (Garces-Bascal, "On Myth"). But exactly how this "empowerment" works through the eyes of the others (i.e. the way Filipinos are seen by the wider global audience as superstitious, highly emotional, and fixed in primitive rural settings) may be deemed problematic, if not counter-productive. Since narratives have the power to shape realities (Fox and Short v; Said,Culture and Imperialism xiii; Smith 6),Gourlay's attempts at empowering Filipinos by perpetuating stereotypes and rehashing essentializing binary oppositions in her novels have repercussions. Particularly, although her novels may indeed succeed in making Filipinos visible in the UK, the quality or nature of the visibility may only cement negative stereotypes Filipinos have been trying to resist.

While Ileto is most critical of Western scholars committing "epistemic violence" against the Filipinos(3-5), Patajo-Legasto ("Introduction" xvii) clarifies that Filipino scholars can also be guilty of orientalist self-representations: "not all writing produced by Filipinos promote the liberation of Filipinos from the material effects of the vestiges of colonialist/classic Orientalist, of contemporary Orientalist and of globalizing discourses." In fact, she points out that "Orientalism, classic or contemporary, is inscribed in studies on our Philippine cultural, historical, and political practices produced by Filipinos" (xvii). Furthermore, Said has long warned against self-orientalism, observing that the "modern Orient...participates in its own Orientalizing"largely reinforced by continued uneven economic, political, and social exchanges (Orientalism 325).

This Orientalist inscription in Philippine scholarship is clear in a number of studies: One example is Hau's analysis of Filipino American writer Hagedorn's novel Dogeaters. Here, Hau exposes its complicity to the continued "othering" of the Philippines by the US: its title, book cover, and different language registers reinforce stereotypical cultural codes of the Other and play upon stock perceptions of the "exoticism" of Filipinos in Westerners' minds ("Dogeaters" 127). Even winners of the Centennial Literary Prizes (1898-1998) (specifically Gamalinda's My Sad Republic, Ong's An Embarrassment of Riches, and Yuson's Voyeurs and Savages), are critiqued

Kritika Kultura 28 (2017): -304 
for "fail[ing] to liberate for they adopt a cavalier attitude toward history and fall prey to the cultural logic of late capitalism" (Laurel 599). The juxtaposition between the Filipino masses and the American landlords in Gamalinda's novel, in particular, strengthens oppressive binary oppositions that favor Americans as rational leaders at the expense of superstitious Filipino fools.

Given the above, Patajo-Legasto thus encourages scholars to adopt a more "critical perspective," that is "a postcolonial position" (beyond geographical or temporal constraints), that confronts and challenges howFilipinos have been and continue to be "constructed or represented as Europe or American's 'ontological Other" (xix). Strongly influenced by Said (Orientalism), she further urges discourses that includes critical theories and creative writings and readings that articulate alternative (oppositional and interventionist) modes of thinking that can "re-define the consciousness of peoples whose identities have been fragmented, whose cultures have been deracinated by the physical and epistemic violence of imperialist incursions and colonialist systems of knowledge" (Patajo-Legasto, "Discoures of 'Worlding"' 8).

\section{“Happy Endings" Privileging the UK over the Philippines}

Admittedly, there are creative strategies of resistance in Gourlay's two novels that disrupt the Western "logical" modes of thinking and narration. As Said asserts, there is "always some form of active resistance" (Culture and Imperialism xii; italics original). For instance, both novels leave lingering questions of mystery/ magic, despite rational/scientific explanations to most superstitions in the plot. In Tall Story, for instance, Nardo's tumor miraculously dies and San Andres has no casualties despite being flattened by the earthquake. Could these be the desiresgranted by the wishing stone? On the other hand, in Shine, Rosa "sees" a fleeting image of Kara's ghost while she was being attacked, and Kat is welcomed to the "other side" by Kara's ghost when she goes "beyond the line of safety" in the sea (Shine 272-3). It is important to note that these unexplained scenes open up tiny spaces for superstitious/supernatural beliefs.

In relation to the above, Boehmer explains that this space of "untranslatable strangeness" where the bizarre and the plausible mingle in postcolonial writing may never be fully accessible to the Western reader: "when representing the mystical or the phantasmic, postcolonial writers elect to withdraw their work, in part, from the hermeneutic space of the West" (236). With this in mind, it can be said that Gourlay's books, which have "a toe dipped in the waters of magic realism" (Ardagh, "Shine by Candy"), allow some space for creative subversion.

Kritika Kultura 28 (2017): -304

(C) Ateneo de Manila University

$<$ http://journals.ateneo.edu/ojs/kk/> 
The narrative style of both children's books can also be interpreted as another strategy of resistance: they avoid the Western chronological narrative sequence, opting instead for an innovative switching back and forth between the past and the present, alternating from one narrator to another, before reaching a climax where the dual elements collide. This "chaotic" narrative structure is reminiscent of Salman Rushdie's Midnight's Children, a novel chronicling mainly the life of Saleem Sinai born in the midnight of India and Pakistan's independence(Ashcroft, Griffiths, and Tiffin 184), and Ninotchka Rosca's State of War, a novel about dictatorship written by a Filipino writer exiled in America (de Manuel 103). However, these subversive potentials are undercut by the stronger privileging of the British over the Filipino: the decisive concluding destination that promises a 'happy ending' to the young protagonists constructs a perspective of 'home that privileges the UK (London) over the Philippines (San Andres and Mirasol).

Of interest to this point is Waddey's contention that home is a central feature in most children's literature. To be specific, Nardo's and Rosa's journey towards "home" follow what Waddey calls the Promethean pattern where home is an "evolving reflection" of the child protagonist (13). This pattern usually starts with the protagonist in some sort of an exile, in which s/he must create his/her own home, which will then define him/her (14). In a sense, both Nardo and Rosa were living lives of exile, hiding and/or just waiting for the inevitable time when they would leave their small towns and move to London. Nardo expressed early on that "home is wherever Ma is" (Tall Story 24), while Yaya repeatedly nagged Dad Jon to move Rosa to London where she could have a "normal life" (Shine 102).

The physical migration to a new "better" home is depicted as "inevitable" (Shine 275). Rosa, even while "bereft" at leaving the only place she has ever called home (284), likens her migration to London to the process of being born:

First, there you are in the darkness of your mother's womb, not knowing anything and not wanting anything to change. And then suddenly you are out, naked and starving hungry in a shining new world. (285)

This concluding description reflects the migratory impulse that has pushed and continues to push many Filipinos away from the "darkness" of their homeland and onto the "shining new world" elsewhere (to London in this case) (Gourlay, Shine 285; San Juan, Filipinos Everywhere). This migratory imperative is also reflected in other works by Filipino Americans: One example is Gotera, who critiques Realuyo's The Umbrella Country (1999) as a "story of dreams and nightmares in the Philippines, where the solution to every problem is America: if we could only get to the US, if we could only be American" (69).

Kritika Kultura 28 (2017): -304

(c) Ateneo de Manila University

<http://journals.ateneo.edu/ojs/kk/> 
Of course, in the two texts by Gourlay, the Philippines will always be remembered fondly as "home": Nardo still seeks for his 'other home' "beyond, over oceans and continents" (Tall Story 224); meanwhile, Rosa still insists that Mirasol is "in every cell of [her] body" (Shine 276). This insistence on rootedness in the homeland even as they leave for "wealthy, distant lands" reflects the contradictions inherent in the nature of Filipino migration (Aguila, Arriola, and Wigley 384). Ultimately, however, the end physical destination that will be the "happy ending" of the literary works will be elsewhere.

In the case of Gourlay's novels, London is the "happy ending" that promises economic stability, family harmony, and even social acceptance since it is painted as a tolerant, multicultural haven.In its "mixing bowl churning with people of every colour." Rosa (like her mother Kara before) will finally be allowed to go out and socialize with others despite resembling a "monster" (Shine 136). Even "giant" Nardo started to look "almost normal" after he wore proper clothes from The Tall Man shop (Tall Story 128). As a result, he becamejust a "tall lad" (97).

Still, Filipino American scholar San Juan cautions us to "disabuse ourselves of the notion that there is equality of cultures and genuine toleration of differences in a stratified society" (From Exile 68). While the UK is "often portrays itself as the European example of a successful multicultural nation," race riots and other disruptions continue to undermine these claims of multiculturalism and immigrant integration (Lacroix 16). More importantly, the complex and opposing motives behind the slim majority of 52 percent to 48 percent in favor to leave the EU in the recent referendum is an indicator of how divided the current British society is in terms of their immigration and multiculturalism policies and practices (Mansur, "Brexit and Multiculturalism").

Despite these instances of growing ambivalence toward multiculturalism in the host country, children's novels penned by Gourlay maintain the UK's promise of a "shining new world" (Shine 285). Her fiction even bends traditions to accommodate the migratory imperative. In the end of Tall Story, Old Tibo claims that Nardo's "power" is able to reach across the world, keeping the people of San Andres safe even when their "savior" is far away. This modern extension to the old folktale presents a convenient compromise between traditional beliefs and contemporary realities: it allows their hero to migrate while simultaneously keeping the myth of Bernardo Carpio alive. As Parlevliet reminds us, the retelling of classic narratives inevitably undergoes adaptations to suit newer contexts and audiences, and are shaped by the dominant ideas/ideals of the rewriting/re-presentation (554). And at this juncture in Filipino migrant labor history, to leave the homeland seems to be the dominant success story. 
At this point, in order to make sense of these "counter-intuitive" representations of the Philippines, the Filipinos, and their culture, it is necessary to turn to Gourlay herself to examine and problematize her role as an "insider" immigrant writer speaking for the "subaltern" Filipinos.

\section{Gourlay as an Immigrant Writer}

In her recent study, Hau ("Privileging Roots" 31) connects the issue of (self-) Orientalism in Philippine scholarship to the issue of Filipino intellectuals' (insider/ outsider) contest over epistemic power and authority in representing the Philippines and Filipinos. That is, she concludes that at the crux of these issues are "questions of the ability, right, and obligation of the intellectual to represent the nation in terms of speaking of and for the country" (30; emphasis mine).

In terms of ability, there seems to be no lack of such. Kondo's study notes a new trend in scholarship in the US (also applicable to other Western/European countries). According to her, "people who were formerly the objects of representation by the dominant are ourselves entering the academy and the arts in order to 'represent ourselves, however problematic that enterprise might be" (qtd. in Hau, "Privileging Roots" 25). This trend ties up with Spivak's rethinking of her earlier assertion that the "subaltern cannot speak" because now the subaltern "is no longer cut off from the lines of access to the center" ("The new subaltern" 326). Gourlay herself has had access to the "center" since the 1990 os when she migrated to the UK with her British husband ${ }^{9}$ and worked as the London correspondent of news agency Inter Press Service and handled a documentary project for BBC Radio 4 (Baines, "Interview with a Debut Author"). Even prior to her migration, Gourlay has had a "voice" with her being educated in one of the top universities in the Philippines and working as a reporter and later on an associate editor of $M r$. E Ms. Special Edition, a magazine dedicated to opposing the Marcos dictatorship in the 1980 os.

In terms of obligation, Gourlay also seems to think it her responsibility as writer to speak for the Philippines and/or Filipinos. In fact, she claims that the problem of lack of diversity in children's fiction is to some extent caused by "writers of colour out there who are not putting their stories forward" ("Multicultural is not about difference"). Hence, she feels some sense of obligation in telling the world "our stories, in our own voices" (Mariano, "Interview with Candy"). Cultural critic Rey Chow addresses this burden of representation that "third world" intellectuals carry in their "first world" existence: Within the postcolonial discursive space that they occupy, these intellectuals are deemed not only "natives" but "spokespersons for the 'natives' in the 'third world." She adds, "the way these intellectuals function is 
therefore inseparable from their status as cultural workers/brokers in diaspora. .." (99).

With her eagerness to carry out her "obligation" as an immigrant writer, Gourlay is fast becoming a recognizable figure in the UK Black, Asian, and Minority Ethnic (BAME) children's fiction industry.Apart from heraward-winning books, active participation in key writers groups, and regular paid school visits, she has been asked to deliver speeches in prominent international conferencesto advocate a more diverse literary landscape in the UK. Some examples are "Why Asia needs more writers for children and young people" which she delivered at the Asian Festival of Children's Content in 2015, and her keynote speech at A Place at the Table in 2016. As a matter of fact, he is even one of the five BAME authors to deliver a masterclass for aspiring BAME children's writers in Megaphone2016-2017, the prestigious mentoring program spearheaded by Leila Rasheed and funded by the Arts Council and Publishers' Association Children's Book Group.

The "counter-intuitive" representational practices discussed earlier may have been informed by a larger factor:the predominantly mono-cultural UK publishing industry that often works on misguided assumptions about the market'sexpectations from immigrant and/or ethnic writers.In the large-scale study funded by the Arts Council of England, Kean shares how BAME writers often feel pressured into using cultural stereotypes in their works: "[they] complained that they were expected to portray a limited view of their own cultures or risk the accusation of inauthenticity if their characters or settings did not conform to White expectations" (3). "Authenticity" problematically comes to mean "exotic," and this is a perception that is resented by many BAME novelists for it emphasizes difference and not the universality of their tales (14). The limiting expectations have, as a result, discouraged many BAME authors and have even driven some away to India or the US in search for book deals.

This troubling misconception of the "authentic" is dependent on the cultural awareness of the largely White editors. Some manuscripts are rejected for not conforming to some "aspect of non-White culture familiar to mainstream White editors" (Kean 8). Hence, statistics show that fewer BAME writers tend to be agented compared to White authors (47 percent versus 64 percent). These problematic assumptions are extended to what editors believe White readers, the (wrongly) presumed majority ${ }^{10}$ of the readership market, are willing toaccept. Meanwhile, for those who are or were able to adjust and get their books published, a majority of BAME novelists share that their ethnicity still takes center stage in the promotion of their books. Furthermore, the BAME angle is deemed the more marketable publicity strategy. Hence, all of these reflect the problematic consequences of the predominantly mono-cultural UK publishing industry (Kean 3). The BAME staff it

Kritika Kultura 28 (2017): -304 
currently employs remains at the junior levels with relatively little decision-making capacities, thus no long-term impact has been executed (Kean 3 ).

Gourlay herself reveals how she is also influenced by the supposed expectations of the dominant market: her very first novel, Dead Cool, which features an English boy who time-travels to an English war, was rejected by her agent who asked, "How am I supposed to sell this book? It has nothing of YOU in it" (Gourlay, "Seizing" 137). That was when Gourlay learned the dictum "Write Who You Are"and not just "Write what you know" (137). Hence, she mined the "wealth of experience and story that [her] heritage had to give" (Sabido, "Author Interview"), resulting in stories driven by traditional folklore and supernatural beliefs, set in far-flung Philippine provinces, and featuring superstitious and emotional Filipinos-precisely the Orientalist ingredients that help sell books by ethnic writers. This trend echoes the insights shared by one Indian author interviewed by Kean (14) who explained that if an "unusual" novel includes "weird rituals or traditions" (e.g. female infanticide, honour killings, forced marriages, holy men molesting children), then it has better chances of publication.

The"burden of representation," which is reinforced by (some authors' collusion with) market expectations and demands, has somehow made the act of representation not just an "obligation" but also a "right" of the "migrant intellectual" who has the wealth of "insider" experience and at the same time the privilege of distance and/or detachment to objectively represent the nation (Hau, "Privileging Roots" 30, 37). But according to author and broadcaster Bidisha, and as supported by interviews with 60 British-based BAME writers, BAME authors who succumb to White readership market expectations risk being seen more as a commentator of one's race and less as an artist who just wants to forward a wonderful idea in a novel (qtd. in Kean 13).

As an immigrant writer, Gourlay admits to being conscious about her role as one of UK's "diverse authors" and is acutely aware of her Filipino audience with both their "shame" over their "weaknesses" (e.g. domestic jobs, broken English, primitive superstitions, etc.) and their obsession over projecting a "positive image" to the rest of the world. Hence, she wants to reaffirm the very "flaws" Filipinos are sensitive about, even describing her books as "love letters" to empower her compatriots: "I was holding up a mirror-look, look, can you see? You are amazing and don't you forget it" (Garces-Bascal, "On Myth”).

However, this good intention can be problematic in two ways: First, the "right" to represent comes with the responsibility of considering the possible repercussions of her representations. In her efforts to boost Filipinos' morale by capturing their sense of humor, "domesticated" English, "showbiz dramatics," spirituality 
bordering on superstition, and strong family ties (Sabido, "Author Interview"), she may have also (unwittingly) reinforced Orientalist stereotypes that could sabotage the reputation of the "invisible" community she has been trying to build up.

Second, Gourlay's use of the mirror metaphor for her novels somehow seems to assume an essential homogeneity among the Filipinos and their cultural heritage. In reality though, Filipinos are a diverse group; therefore, these "mirror"-like novels should reflect multiple images cut across socio-economic status, gender, class, religion, language, and other critical angles that complicate people's cultural or racial identities (Dudley-Marling 311).

Noll reminds us that insider children's literature writers also have varied cultural understandings as influenced by their different upbringing (184). Gourlay herself is an educated, middle-class, privileged Filipino whose conditions and process of migration to the "center" do not mirror those of the Filipino nurses in the novels or of other Filipinos in real life. Her representational practices maythus run the risk of being deemed as a kind of "Oriental consent" (Said, Orientalism 325).

However, to be fair, it is important to note that (especially in her blog posts this past year) Gourlay keenly feels and constantly reevaluates her own role as a Filipino writer in London. Even while being labeled as one of UK's "diverse authors," Gourlay does not seem to be fully comfortable with all the connotations of "diversity" with its politics of inclusion, cultural appropriation, and (anti-) racism. She herself admits to having trouble navigating issues of representation in her current work on a book set in the 190os, narrated by a boy who belongs to a particular tribe in the Bontoc province in the Philippines. ${ }^{11}$ She shares her rigorous research process of sifting through original documents and diaries that describe the tribefrom that era, but she admits to notfinding any text sourced from the tribe itself. As such, she is wary about her "right" to create a hero from a background that does not have a "voice" (no first-hand documentation) and one to which she does not belong. She concedes to simply writing the best book she can and hoping that her efforts will not be seen as attempts to "drown out or overshadow anyone but encourage them to tell their own stories."

Thus, despite the risky representational practices exposed and cautioned against in this paper (perhaps due more to the dynamics of and pressure from the UK publishing industry gatekeepers), Gourlay seems to grow moreconscientious and self-reflexiveas she embraces and struggles with her role as a writer straddling two cultures. Spivak calls this necessary critical stance the systematic "unlearning of one's privilege,"which means realizing how one's very ability to speak for an-Other is already a reflection of one's privileged position within the dominant structure, and understanding how the project of representation may not necessarily empower

Kritika Kultura 28 (2017): -304 
the silenced, but may even move them deeper into the margins ("Strategy" 42). The process of "unlearning one's privilege" requires listening more closely to the 'other' and creating opportunities and space for them to actually answer back (42). Chow thus boldly challenges "third world" intellectuals to resist the "lures of diaspora": "What one can do without is the illusion that, through privileged speech, one is helping to save the wretched of the earth" (119), unless perhaps if this "privileged speech" critically addresses the historical and socio-political conditions that allowed its own articulation. Otherwise, the "benevolent" service of "speaking for" the "subalterns" will only contribute to the hegemonic structure that silenced them in the first place (i.e. neoliberal mechanisms that welcome labor immigrants yet insists on their "invisible" status in the host country) (San Juan, Filipinos Everywhere).

\section{CONCLUSIONS}

The power of children's literature lies in its ability to explore serious social issues while at the same time providing "outlets for magic and fantasy" to stimulate readers' curiosity and imagination (Thirumurthy 446). Gourlay's Tall Story and Shine exemplify both potentials: they turn the attention of global readers to the "invisible" Filipino minority in the UK, narrating (with subtle social critique) both their motivations for migration and their serious labor migration woes including torn families, visa delays, homesickness, and cultural adjustments to new homes. These narratives unfold in a creative manner infused with folklore and supernatural elements that not only introduce Filipino heritage to foreigners, but also provide cultural educationto second- and/or third-generation Filipinos in the UK who are unfamiliar with their own roots. Judging from the novels' multiple inter/national acclaims and positive reviews, Gourlay has accomplished quite a feat in writing the "invisible" Filipinos into some level of visibility in the UK.

However, orienting readers about a particular ethnic group is not a simple matter of foregrounding them and narrating their migrant experiences. Given the didactic nature of the genre that can "fill the gaps of historical memory, subvert ethnic stereotypes, and advance revisionary versions of cultural identity" (Smith 6), representations embedded therein are critical. Unfortunately, as discussed earlier, the geographic, cultural, and gender representations in Gourlay's books reveal selforientalizing traces that may reinforcearbitrary East-West divide where the East/ Oriental/Filipino are stuck with negative essentializing stereotypes. Moreover, the "happy ending" pattern in both novels somehow promotes the dominant migratory impulse privileging "shining new world" of London over the "darkness" of the Philippines (Shine 285).

Kritika Kultura 28 (2017): -304

(C) Ateneo de Manila University

$<$ http://journals.ateneo.edu/ojs/kk/> 
Ultimately, this paper argues that Gourlay's two children's books have doubleedged consequences: they provide some form of visibility to "invisible" Filipinos in the UK, but the kind of visibility offered by these market-approved books runs the risk of reinforcing presumed market expectations from an immigrant "third world" author writing in the center, that is, representations consistent with their stock perceptions of the "Otherness" of Filipinos, especially when pitted against the British center.

The counter-intuitive representations, as a result, compel us to problematize the immigrant writer's role, the publishing context s/he is in, and the very act or process of "speaking for" "others," which in itself is already problematic in its assumptions of homogeneity and lack of agency of the "others" represented as well as in its reliance on the unequal distribution of power that allows one the privilege of speech (over others) in the first place.

The question of intellectual authority or "right" to speak for "others" is "neither neutral nor merit based" (Hau, "Privileging Roots" 53). Writers have their own subjective assessments of the immigrant community as influenced by his/her own personal background (i.e. class, gender, religion, etc.). Immigrant writers speaking for other "subaltern" immigrants also face the dilemma of negotiating the demands and expectations of multiple audiences: bothinsiders and outsiders, children and adults, "lay" readers and publishing gatekeepers (i.e. editors, literary agents, among others). Additionally, Smith contends that there iscomplexity in how writers grapple with this task (4). For instance, ethnic children's literature writers typically hope to change readers' minds: "resistance to pejorative categorizations" is encouraged among readers whose ethnicities are represented, while "cross-cultural amity and understanding" is aimed for readers from other ethnic groups (4). However, amidst the multiple conflicting demands and expectations (e.g. empowering Filipino migrants, getting published in a competitive field, among others), those of the dominant group's may be prioritized (i.e. giving in to the market's "exotic" cravings from "third world" immigrant writers).

However, this paper does not aim to discount the efforts of immigrant writers like Gourlay to put Filipinos (or other minor ethnic groups in the UK) on the map of British literary landscape and consciousness. In fact, Gourlay's award-winning novels are laudable efforts of getting Filipinos included in what Moore-Gilbert describes as the "long and rich tradition" of British immigrant literature that has allowed the representation of different communities in the UK(99).

Instead, the aim of this paper is to illustrate the powerful "imaginative command" ofliterature in perpetuating ideas/ideals (Boehmer 5). Stories matter: "They influence the ways in which children [and adults] think about themselves and their place in

Kritika Kultura 28 (2017): -304 
the world as well as the ways in which they think about other cultural perspectives and peoples" (Fox and Short v). Hence, immigrant writers who grapple with the burden of representationface the challenge of critically negotiating conflicting demands and expectations of various audiences/stakeholders, of continuously reflectingon their own personal (privileged) positions of articulation, and most importantly, of being vigilant about the double-edged potentials of their attempts at "speaking for" "Others." 


\section{Notes}

1. SCBWI is a professional organization dedicated to serving writers, illustrators and other interested stakeholders in the field of children's literature

2. SOA is a company registered in England that aims to further the interests and protect the rights of professional writers.

3. Some of her usual presentations in her school visits include "The Hero's Journey" (a presentation on the fundamental pattern in most great narratives), "The Mythology of Geography" (using the Philippines to discuss how living with disaster influences people's mythologies and affects their belief systems), and "30o Word Challenge" (a creative writing workshop for kids). According to her "School Visit Flyer", her rate for single presentation and meet the author is $£ 250$ (in line with the average rate stipulated in the Society of Authors).Gourlay has also extended her school visits to the virtual world. Using Google Hangout, she was able to interact with the six graders of Smith Middle School in North Carolina, USA in the latter part of 2014. She did candidly mention once that her books were not be faring quite so well in the US market as the paperback release of Tall Story was met by a "deafening silence."

4. In her December 13, 2013 blog post, Gourlay responds to the creative works and letters she received from the Year Sevens of Ellis Guilford, Nottingham after she visited them in October 2013. (The letters are a mix of drawings, author interview questions, as well as touching concern for Filipinos after we were hit by Haiyan typhoon in November 2013.) Tall Story was included in the Christmas reading list and Reader's Cup Challenge activity of students at Thomas' Day School, Battersea, London. (Gourlay shared a video of their competition in her January 17, 2012 blog). Shine was also included in "The Gr8 Book Debate" held in Swindon schools: between Ridgeway School and Sixth Form College, Isambard Community School, and Nova Hreod Academy (July 5, 2016).

5. Gourlay also posted on September 21, 2014 about "the school run to end all school runs" where in just a matter of weeks (September 13 to October 1), she delivered talks, writing workshops, book launch, and a series of school visits that include Bradbury and Glenealy schools in Hong Kong, and more than ten schools in the Philippines (e,g, Ambulong Elementary School and Janopol Elementary Schools in Batangas, the Beacon Academy in Laguna and in Makati, Xavier Nuvali, Poveda, Ateneo de Manila, St. Theresa's College to name a few).

6. Tall Story alternates between two half-siblings who initially lived apart: eight feet tall, sixteen-year-old Nardo (Bernardo) from San Andres, Philippines, and thirteen-year-old basketball fanatic Andi (Amandolina) in London. Whereas Andi has been living a typical teenage life, Bernardo has been living the life of a local legend. With his unexplainable growth spurt mysteriously coinciding with the sudden stop of regular earthquakes in their town, people started believing him to be the reincarnation of Bernardo Carpio-a giant who, according to local folklore, used his massive strength to stop two walls of rock from colliding with each other

Kritika Kultura 28 (2017): -304

(C) Ateneo de Manila University

<http://journals.ateneo.edu/ojs/kk/> 
and devastating the whole town. Thus, when the British Home Office finally approved Bernardo's long-delayed visa petition, the townspeople considered it a problem. They feared that they would be left vulnerable without their 'savior'. The novel weaves through the mysteries and superstitions of Bernardo's life back in San Andres and his difficult yet exciting adjustments to life in London with his mother and new family.

7. Like in her debut novel, Gourlay presents two narrators and two settings in Shine: the primary one is Rosa, a thirteen-year-old British Filipina who suffers from a rare condition called "the Calm." This incurable but non-life threatening condition has rendered her mute, with ugly shriveled folds at the base of her throat. Together with her British dad, Jon (a specialist in 'the Calm') and her Yaya (maid), Rosa lives in Mirasol, Philippines, where rain and fear reign. Since townspeople believe that those with "the Calm" are monsters, Rosa is forced to live an isolated life, hidden away in their remote house with only the Internet as a source of social life. Strongly influenced by the ghost stories of Yaya and by the superstitious attitude of the island, Rosa lights a candle on her windowsill every night hoping to summon her mother's ghost-the other narrator in the novel. Kara, who also suffered from 'the Calm', brings readers back to the past and narrates her complex relationship with her 'normal' mirror twin, Kat. From Mirasol, they migrated to London for a better life, but their relationship turned sour due to a love triangle with Jon. These two narratives converge at a thrilling climax where key characters were forced to confront ghosts and monsters they thought they have already laid to rest.

8. Both Nick (26 years old) and Mia (18 years old) hold dual citizenship while Jack (20 years old was in the process of doing the same at the time of the interview by De Vera ("Identity crisis spawns 2 books").

9. Richard Gourlay used to be the Financial Times of London's correspondent in Manila, but is now managing a venture capital fund in London. He tried to gain Filipino citizenship (to make his citizenship dual like his children) but his attempt was unsuccessful (De Vera, "Identity crisis spawns 2 books").

10. Kean predicts that by $2051,20 \%$ of the UK population will be from some ethnic minority, so the average British reader in the next 30 years would likely be "an educated young woman of mixed heritage" (2). It is thus imperative that the publishing industry be ready to write for this future readership, or they will risk becoming culturally irrelevant.

11. She further shares in an interview by De Vera that this book will be followed by a second one detailing the boy's experiences in the infamous Philippine exhibit at the 1904 World's Fair in St. Louis, Missouri.

Kritika Kultura 28 (2017): -304 


\section{Works Cited}

Abad-Jugo, Cyan. "Killing time: The Condition of Exile in the Fiction of Jose Y. Dalisay, Jr." Kritika Kultura, vol. 10, 2008, pp. 57-79.

Aguila, Augusto Antonio, Joyce Arriola, and John Jack Wigley. Philippine Literatures: Texts, Themes, Approaches. UST, 2008.

Alba, Reinero. "Nurturing Children's Literature in the Philippines." National Commission for Culture and the Arts. 28 July 2003, www.gwhs-stgo2.i.gov.ph/ S2nccagovph/aboutculture-and-arts/in-focus/nurturing-childrens-literature-in-the-philippines. Accessed 5 June 2014.

Ardagh, Philip. "Shine by Candy Gourlay - Review." The Guardian, 18 January 2014, www. theguardian.com/books/2014/jan/18/shine-candy-gourlay-review. Accessed 20 May 2014.

Ashcroft, Bill, Gareth Griffiths, and Helen Tiffin. The Empire Writes Back: Theory and Practice in Post-colonial Literatures. Routledge, 1994.

Aziz, Seemi. "Issues within Picture Books Representing Pakistan and Afghanistan." Children's Literature: A Global Montage, Childhood Education, International Focus Issue, vol.87, no.6, 2011, pp. 444-5.

Baines, Tracy Ann. "Interview with a Debut Author: Candy Gourlay." Tall Tales and Short Stories. 10 May 2010, www.talltalesandshortstories.blogspot.co.uk/2010/05/interviewwith-debut-author-candy.html. Accessed 29 July 2014.

Bhabha, Homi. Nation and Narration. Routledge, 1990.

Boehmer, Elleke. Colonial and Postcolonial Literature: Migrant Metaphors.1995. Oxford UP, 2005.

Bradford, Clare. "The End of Empire? Colonial and Postcolonial Journeys in Children's Books." Children's Literature, vol. 29, 2001, pp. 196-218.

Buchan, James. "Filipino Nurses in the UK: A Case Study in Active International Recruitment." Harvard Health Policy Review, vol.7, no.1, Spring 2006, pp. 113-20.

Cheung, King-Kok. "Re-viewing Asian American Literary Studies." An Interethnic Companion to Asian American Literature, edited by King-Kok Cheung, Cambridge UP, 1997, pp. 1-36.

Chow, Rey. "Against the Lures of Diaspora." Writing Diaspora: Tactics of Intervention in Contemporary Cultural Studies, edited by Rey Chow, Indiana UP, 1993, pp. 99-119.

Corbyn, Mark. "Ticking All the Right Boxes: British-Filipinos and the 2011 UK census." Philippine Generations. 17 Feb. 2011, www.philippinegenerations.org/2011/o2/tickingall-the-right-boxes-british-filipinos-and-the-2011-uk-census.html. Accessed 25 Aug. 2016.

Davis, Rocío. "Have Come, Are Here: Reading Filipino/a American Literature." MELUS,vol. 29, no.1, Spring 2004, pp. 5-18.

de Manuel, Dolores. "Decolonizing Bodies, Reinscribing Souls in the Fiction of NinotchkaRosca and Linda Ty-Casper." MELUS, vol. 29, no. 1, Spring 2004, pp. 99-118. 
de Manuel, Dolores, and Rocío Davis. "Editors' Introduction: Critical Perspectives on Asian American Children's Literature." The Lion and the Unicorn, vol. 30, no. 2, Apr. 2006, pp. v-xv.

De Vera, Ruel. "Tall Story: Tale of 2 siblings, 2 cultures." Philippine Daily Inquirer.15 Aug. 2010, http://newsinfo.inquirer.net/inquirerheadlines/nation/view/20100815-286857/ Tall-Story--Tale-of-2-siblings-2-cultures. Accessed 27 June 2014.

--. "Identity crisis spawns 2 books by awarded, UK-based Filipino Candy Gourlay." Philippine Daily Inquirer. 21 Sept. 2014, http://globalnation.inquirer.net/111447/ identity-crisis-spawns-2-books-by-awarded-uk-based-filipino-candy-gourlay. Accessed 23 Aug. 2016.

Dudley-Marling, Curt. 'I'm not from Pakistan': Multicultural Literature and the Problem of Representation." Stories Matter: The Complexity of Cultural Authenticity in Children's Literature, edited by Dana L. Fox and Kathy G. Short, National Council of Teachers of English, 2003, pp. 304-18.

Faber, Polly. "Shine and Picture Me Gone." The Little Wooden Horse.8 Oct. 2013, http:// thelittlewoodenhorse.blogspot.co.uk/2013/10/shine-and-picture-me-gone.html. Accessed 27 June 2014.

Fox, Dana, and Kathy Short. Stories Matter: The Complexity of Cultural Authenticity in Children's Literature. National Council of Teachers of English, 2003.

Garces-Bascal, Myra. "On Myth, Magic, and Multicultural Storytelling: Candy Gourlay's Thoughts about Tall Story." Gathering Books. 26 May 2012, http://gatheringbooks. org/2012/05/26/on-myth-magic-and-multicultural-storytelling-candy-gourlaysthoughts-about-tall-story. Accessed 29 July 2014.

González, BegoñaSimal. "Flipping Across the Ocean: Nostalgia, Matchmaking and Displacement in Filipino American Narrative." Odisea, vol.1, 2001, pp. 39-48.

Gonzalez, Nestor, Vicente Madali, and Oscar Campomanes. "Filipino American Literature." An Interethnic Companion to Asian American Literature, edited by King-Kok Cheung, Cambridge UP, 1997, pp. 62-124.

Gotera, Vince. "Brave New Archipelago: Recent Filipino American Writing." North American Review, vol. 287, nos. 3-4, 2002, pp. 69-72.

Gourlay, Candy. Tall Story. David Fickling Books, 2010.

--. Shine. David Fickling Books, 2013.

--. "Seizing the Sword: a Writer's Journey." Beyond Folktales, Legends, and Myths: a Rediscovery of Children's Literature in Asia, edited by Myra Garces-Bascal and Jesus Federico Hernandez. AFCC, 2013, pp. 134-39.

--. "Multicultural is not about Difference but Inclusion: Why the Children's Book World has to be a Coat of Many Colours." Candy Gourlay 2 Dec. 2013, www.candygourlay. com/2013/12/multicultural-is-not-about-difference.html. Accessed 31 July 2014.

Gourlay, Candy, Teri Terry, EmLynas, Addy Farmer, Jo Wyton, Nick Cross, Kathryn Evans, and Paula Harrison. Notes from the Slushpile. 2016, www.notesfromtheslushpile.com/p/ about-notes-from-slushpile.html. Accessed 20 Aug. 2016. 
Hau, Caroline. "Dogeaters, Postmodernism and the 'Worlding' of the Philippines." Philippine Postcolonial Studies: Essays on Language and Literature, edited by Cristina Pantoja Hidalgo and PriscelinaPatajo-Legasto, U of the Philippine P, 2004, pp. 116-30.

--. "Privileging Roots and Routes: Filipino Intellectuals and the Contest over Epistemic Power and Authority." Philippine Studies: Historical and Ethnographic Viewpoints, vol. 62, no. 1, March 2014, pp. 29-65.

Ileto, Reynaldo. "Orientalism and the Study of Philippine Politics." Philippine Political Science Journal, vol. 22, no. 45, 2001, pp. 1-32.

Kean, Danuta, editor. "Writing the Future: Black and Asian Writers and Publishers in the UK Market Place." Spread the Word. Arts Council England, April 2015.

Lacroix, Chantal. Immigrants, Literature, and National Integration. Palgrave MacMillan, 2010.

Lapeña-Barayuga, Luz. "Home and Exile in Five Contemporary Novels by Filipinos in America." Unpublished Ph.D diss., Saint Louis University, Baguio City, Philippines. Jan. 1997, www.dspace.slu.edu.ph/bitstream/123456789/288/1/Luz\%2oLapena-Barayuga\%20 Dissertation.pdf. Accessed 28 May 2014.

Laurel, Robert Kwan. "A Hundred Years after the Noli: the Three Centennial Novels in English." Philippine Studies, vol. 51, no. 4, 2003, pp. 599-643.

Lazim, Ann. "Reading Our World: Multicultural Books." Booktrust. 2014, www.booktrust. org.uk/books/children/books-from-around-the-world/multicultural-books. Accessed 11 June 2014.

Legarda-Alcantara, Carmila, Maria Gonzalez, Candy QuimpoGourlay, Ed Maranan, and Jamie Tapales Oakes. Hinabing Gunita (Woven Memories): Filipinos in the United Kingdom. The Centre for Filipinos, 2004.

MacAlpine, Sue. "Foreword." HinabingGunita (Woven Memories): Filipinos in the United Kingdom, edited by CarmilaLegarda-Alcantara, Maria Gonzalez, Candy QuimpoGourlay, Ed Maranan, and Jamie Tapales Oakes, The Centre for Filipinos, 2004, pp. 13-14.

Mansur, Salim. "Brexit and Multiculturalism." American Thinker, 26 June 2016, www. americanthinker.com/articles/2016/o6/brexit_and_multiculturalism.html. Accessed 25 Aug. 2016.

Mariano, Anthony. "Interview with Candy Gourlay, Author of Tall Story and Shine." Sambat Trust: supporting literacy and education in the Philippines. 12 Mar. 2014, www. sambattrust.org/blog/interview-with-candy-gourlay-author-of-tall-story-and-shine. Accessed 25 May 2014.

McGillis, Roderick. "Self, Other, and Other Self: Recognizing the Other in Children's Literature." The Lion and the Unicorn, vol. 21, no. 2, April 1997, pp. 215-229.

Miller, John Maurice, Mabel Cook Cole, Nita Umali-Berthelsen, Jose Rizal, Alfonso Santos, and F. Landa Jocano. "Bernardo Carpio." Filipino Martial Arts Digest Special Edition: Philippine Mythology and Folklore, 2007, pp. 21-22.

Moore-Gilbert, Bart. "British Immigrant Literature." Encyclopedia of Literature and Politics: Censorship, Revolution, and Writing, vol. 1: A-G, edited by M. Keith Booker, Greenwood P, 2005, pp. 99-100. 
Nodelman, Perry. “The Other: Orientalism, Colonialism, and Children's Literature.” Children's Literature Association Quarterly, vol. 17, no.1, Spring 1992, pp. 29-35.

Noll, Elizabeth. "Accuracy and Authenticity in American Indian Children's Literature: The Social Responsibility of Authors and Illustrators." Stories Matter: The Complexity of Cultural Authenticity in Children's Literature, edited by Dana L. Fox and Kathy G. Short, National Council of Teachers of English, 2003, pp. 182-97.

Paman, Alex. "Beneath the Pale Moonlight: the Filipino Supernatural in the Asian/Pacific Context." Positively Filipino. 30 Oct. 2013, www.positivelyfilipino.com/magazine/somethings-wicked-this-way-come Accessed 21 July 2014.

Parlevliet, Sanne. "Foxing the Child: the Cultural Transmission of Pedagogical Norms and Values in Dutch Rewritings of Literary Classics for Children 1850-1950." Paedagogica Historica, vol. 48, no. 4, 2012, pp. 549-570.

Patajo-Legasto, Priscelina. "Introduction: Discourses of 'Worlding' and the Philippine Postcolonial Studies." Philippine Postcolonial Studies: Essays on Language and Literature, edited by Cristina Pantoja Hidalgo and Priscelina Patajo-Legasto, U of the Philippine P, 2004, pp. 3-17.

--. "Introduction." Philippine Studies: Have We Gone Beyond St. Louis?, edited by Priscelina Patajo-Legasto, U of the Philippine P, 2008, pp. xv-xxiii.

Popiel, Kathryn. "A Sense of Home?" Hinabing Gunita (Woven Memories): Filipinos in the United Kingdom, edited by Carmila Legarda-Alcantara, Maria Gonzalez, Candy Quimpo Gourlay, Ed Maranan, and Jamie Tapales Oakes, The Centre for Filipinos, 2004, pp. 188-192.

Rasheed, Leila. “Children's literature: For white children only?” VulpesLibris. 28 Sep. 2015, https://vulpeslibris.wordpress.com/2015/09/28/childrens-literature-for-white-childrenonly/. Accessed 25 Aug. 2016.

Reyes, Melanie. "Migration and Filipino Children Left-Behind: a Literature Review." Miriam College Women and Gender Institute (WAGI) and UNICEF Philippines, 2008, www.unicef.org/philippines/Synthesis_StudyJuly12008.pdf. Accessed 22 July 2014.

Sabido, Tarie. "Author Interview: Candy Gourlay." Asia in the Heart, World on the Mind. 30 Nov. 2009, http://asiaintheheart.blogspot.co.uk/2009/11/what-was-spark-that-set-youoff-writing.html. Accessed 29 July 2014.

Said, Edward. Orientalism. Vintage Books, 1978.

--. Culture and Imperialism. Vintage Books, 1994.

San Juan, Epifanio Jr. From Exile to Diaspora: Versions of the Filipino Experience in the United States. Westview, 1998.

--. Filipinos Everywhere: Displaced, Transported Overseas, Moving on in the Diaspora. IBON Foundation, 2006.

Santos, Ana. "Why Filipinos Left: A History of Migration." Rappler. 1 July 2014,www. rappler.com/move-ph/issues/62055-history-migration-filipinos. Accessed 1 July 2014.

Scalabrini Migration Center. Hearts Apart: Migration in the Eyes of Filipino Children. Episcopal Commission for the Pastoral Care of Migrants and Itinerant People-CBCP/ Apostleship of the Sea-Manila, 2004.

Kritika Kultura 28 (2017): -304 
Schmidt, Nicky. "An Interview with Debut Children's Author, Candy Gourlay." Absolute Vanilla. 27 June 2010, www.absolutevanilla.blogspot.co.uk/2010/o6/interview-withdebut-childrens-author.html. Accessed 29 July 2014.

Smith, Katharine Capshaw. "Introduction: the Landscape of Ethnic American Children's Literature." MELUS, vol. 27, no. 2, 2002, pp. 3-10.

Spivak, Gayatri Chakravorty. "Can the Subaltern Speak?" Marxism and the Interpretation of Culture, edited by Cary Nelson and Lawrence Grossbert, U of Illinois P, 1988, pp. 271-313.

-. "Strategy, Identity, Writing." The Post-Colonial Critic: Interviews, Strategies, Dialogue Gayatri Chakravorty Spivak, edited by Sarah Harasym, Routledge, 1990, pp. 35-49.

--. "The New Subaltern: a Silent Interview." Mapping Subaltern Studies and the Postcolonial, edited by Vinayak Chaturvedi, Verso, 2000, pp. 324-340.

"The South-East Asia Diaspora in the UK." Foreign and Commonwealth Office. 2011,www. gov.uk/government/uploads/system/uploads/attachment_data/file/384758/SE_Asia_ II_2_.pdf. Accessed 25 Aug. 2016.

Thirumurthy, Vidya. "Building Cultural Bridges through International Children's Literature." Childhood Education, vol. 87, no. 6, 2011, pp. 446-7.

Waddey, Lucy. "Home in Children's Fiction: Three Patterns." Children's Literature Association Quarterly, vol. 8, no.1, Spring 1983, pp. 13-5. 